\title{
Evolution of a Disseminated Peritoneal Leiomyomatosis: About a Case
}

\section{Kouamé Arthur Didier ${ }^{1}$, Adjoby Cassou Roland ${ }^{1}$, Koffi Achille', Konan K. Joachin'1, Alla Christian Hervé1, Kouamé N’Da Justin'², I. S. Baldé3 ${ }^{3}$ Kouakou Firminn ${ }^{1}$}

${ }^{1}$ Obstetrics and Gynecology Department, University Hospital of Cocody, Abidjan, Côte D’Ivoire

${ }^{2}$ Laboratory of Pathology, University Hospital of Cocody, Abidjan, Côte d'Ivoire

${ }^{3}$ Obstetrics and Gynecology Department of Ignace Deen Hospital of Conakry, Conakry, Guinea

Email: *Arthur.kouame@mail.huji.ac.il

How to cite this paper: Didier, K.A., Roland, A.C., Achille, K., Joachin, K.K., Hervé, A.C., Justin, K.N., Baldé, I.S. and Firmin, K. (2017) Evolution of a Disseminated Peritoneal Leiomyomatosis: About a Case. Open Journal of Obstetrics and Gynecology, 7, 742-747.

https://doi.org/10.4236/ojog.2017.77075

Received: May 17, 2017

Accepted: July 11, 2017

Published: July 14, 2017

Copyright ( 2017 by authors and Scientific Research Publishing Inc. This work is licensed under the Creative Commons Attribution International License (CC BY 4.0).

http://creativecommons.org/licenses/by/4.0/

\begin{abstract}
Disseminated peritoneal leiomyomatosis (DPL) is a benign tumor of smooth muscle tissue. It is rare and is characterized by the development of multiple peritoneal nodules simulating peritoneal carcinosis. Less than 200 cases have been reported in the literature so far. We are reporting a case of DPL detected during a Caesarean section 6 years ago in a 41-year-old female patient, G5P2. The patient underwent an elective iterative caesarean section at 38 weeks of amenorrhea for a fetus in breech presentation. During laparotomy, there was a marked regression of the peritoneal nodules varying in size from 0.1 to 0.5 $\mathrm{cm}$. Histological examination showed a proliferation of smooth muscle fibers without mitosis, atypia or necrosis. DPL is a benign, confusing condition that simulates peritoneal carcinomatosis, which must be recognized as such in order to avoid a dilapidated and unnecessary surgical procedure.
\end{abstract}

\section{Keywords}

Disseminated Peritoneal Leiomyomatosis, Uterine Leiomyoma, Caesarean Section

\section{Introduction}

Disseminated peritoneal leiomyomatosis (DPL) is a benign tumor of smooth muscle tissue. This rare condition is characterized by the development of multiple peritoneal nodules simulating peritoneal carcinosis [1] [2]. We present here the evolution of a case fortuitously discovered 6 years ago during a caesarean section [3].

\section{Case Presentation}

A 41 years old woman, G4P2 was admitted to the maternity of the University 
Hospital of Cocody (Abidjan, Côte d'Ivoire) for an elective iterative elective, indicated for a fetus in breech presentation in 2015. In her personal medical background, the first child was delivered vaginally. A second child was born 6 years ago by caesarean section for fetal macrosomia $(4600 \mathrm{~g})$. She also underwent two unsafe abortions. She has never used contraceptives because of a desire for maternity and has no history of uterine fibroid. At admission, a good general condition was noted. Her blood pressure was $12 / 8 \mathrm{~cm} \mathrm{Hg}$, weighted $82 \mathrm{~kg}$ with 161 $\mathrm{cm}$ tall. The uterine height was estimated at $32 \mathrm{~cm}$. The fetal heart rate was normal. The uterus was supple at palpation examination. The speculum examination was without peculiarities. At the vaginal touch, the lower segment was poorly amplified, the presentation was inaccessible. Examination of the other apparatus was clinically normal.

Obstetric ultrasound showed a fetus in breech presentation with an estimated fetal weight of $3200 \mathrm{~g}$. Biological examinations performed as part of the preoperative assessment were normal.

The caesarean allowed the extraction of a fetus of $3100 \mathrm{~g}$, Apgar at $8-9$ in 1 and $5 \mathrm{mn}$. During the Caesarean section, there was a clear regression of DPL nodules with a size varying between 0.1 and $0.5 \mathrm{~cm}$ disseminated in the pelvic cavity. These nodules were visible on the right broad ligament, on the utero-vesical peritoneum, on the pelvic colon, on the omentum (Figure 1 and Figure 2). Before abdominal closure, nodular biopsies are performed for pathological examination. This examination confirms a proliferation of smooth muscle fibers without mitosis or atypia or necrosis. Leiomyosarcoma is discarded in the absence of necrosis and morphological features of malignancy, a low proliferation index and clinical context (absence of pulmonary localizations). The post operative follow-up was uneventful and the patient was discharged from the hospital in the 5th Postoperative day for ambulatory follow-up in accordance with the maternity protocols.

\section{Discussion}

Disseminated peritoneal leiomyomatosis (DPL) is a rare disease. From the Wilson and Peale princeps observation in 1952 and the DPL designation by

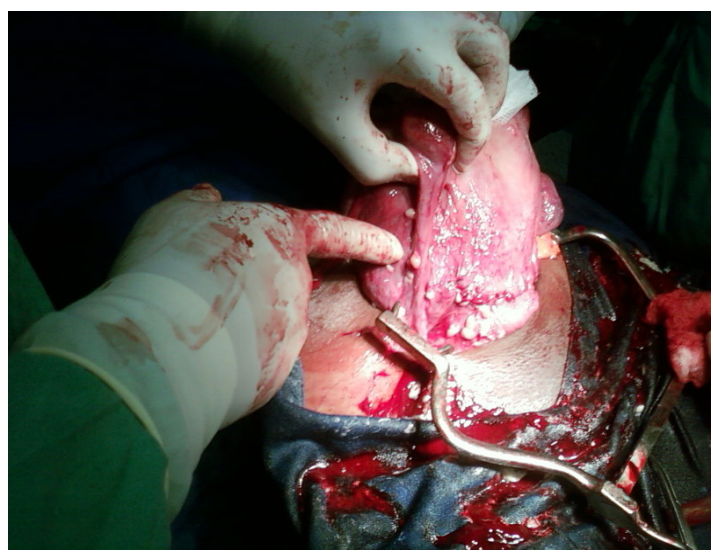

Figure 1. Photo showing DPL nodules 6 years before. 


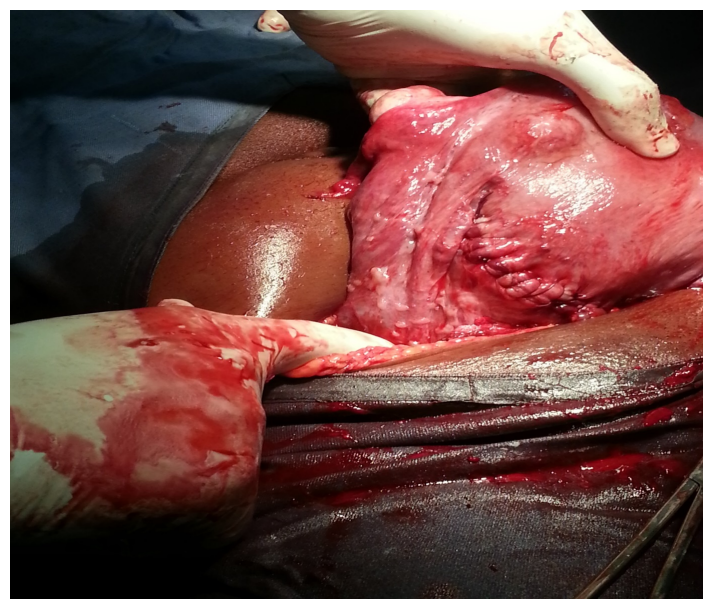

Figure 2. Photo showing DPL nodules in the same woman 6 years after.

Taubert et al. In 1965, a large review of the Anglo-Saxon literature has made it possible to identify between 150 and 200 reported cases to date [4] [5]. The evolutionary and therapeutic follow-up of DPL remains unlikely and often little codified. The etiology is unknown but DPL appears as a multifactorial disease, hormonal factors (high levels of estrogen and progesterone) or genetic factors that can lead to metaplasia of peritoneal mesenchymal cells [6] [7]. Some iatrogenic factors are also mentioned, the example of the rise of laparoscopic surgery in the management of uterine fibroids by the technique of breaking up [4] [5] [8] [9].

The high frequency of DPL in the period of genital activity, including the gravidic period (our observation) validates the idea of hormonal involvement in the genesis of DPL [3] [7].

\section{Diagnosis}

In practice, there is no clinical expression of DPL. The patients are generally asymptomatic and the diagnosis is fortuitous during a coeliotomia. The contribution of radiology imaging to diagnosis does not seem decisive. The biopsy and the histological study of the biopsy sample are the cornerstone of the diagnosis. The histological examination shows a spindle proliferation of smooth muscle fibers without mitosis or necrosis, without atypia or with low grade atypia [2] [4] [10]. Differential diagnoses are parietal leiomyomas, intravenous leiomyomatosis and other peritoneal carcinomatosis [2].

\section{Therapeutic, Management and Prognosis}

For treatment, therapeutic abstinence is accepted by most authors, after an extemporaneous examination of the samples to determine the histological nature [1] [5]. DPL manifests itself in adulthood and affects women essentially. The majority of cases are asymptomatic but manifestations have been reported such as abdominal and pelvic pain, rectal or vaginal bleeding, and gastrointestinal disorders more rarely. The risk of malignant transformation is rare but not nil. 
Indeed, eight cases of malignancy have been reported in the literature. According to Yamaguchi and Sharma in about $2 \%-5 \%$ of cases, a progression towards malignancy can be observed [11] [12].

Lower levels of sex hormones, for example, following surgical castration or contraception, lead to regression of the disease. Depletion of ovarian functions with a gonadotropin agonist may lead to a reduction in nodules [13]. According to $\mathrm{Wu}$ et al., with women who no longer desire maternity, total abdominal hysterectomy with bilateral salpingo oophorectomy, Omentectomy and tumor reduction may be an optimal treatment [5].

In our case the surveillance was based on CT scan and gynecological clinical monitoring. During the 6 years after the first Caesarean section, there was no major symptomatology requiring specific radiological and biological investigations. The patient had a desire for maternity, hence the refusal of any contraception (hormones such as oral contraceptives should be interrupted) and/or hormonal treatment.

In addition, cases of favorable progression through surgical ablation of nodules have also been reported and hormone therapy is proposed to avoid recurrence, but no definitive therapeutic concept has been evaluated so far [10]. Depending on the extent of the disease, the first line treatment of DPL would be surgical excision or cytoreduction for some authors. Systemic chemotherapy has been proposed as a therapeutic option in the rare cases of inextricable or metastatic tumors [14] [15] [16].

In our observation, clinical and radiological follow-up (pulmonary radiography, computed tomography scan) did not highlight any complications. The second Caesarean section, on the other hand, showed a marked regression of the nodules. In the literature, cases of spontaneous regression are mentioned [7]. No particular follow-up was therefore proposed following this second Caesarean section, however, in view of any suspicious symptomatology, imagery will be used. Monitoring should be continued until menopause.

Ultimately, treatment, if necessary, is based on stopping the hormonal stimulus (bilateral adnexectomy if peri-menopause, LH-RH analogues, anti-estrogens, progestogens). Treatments are being tested as LPD complementary treatment such as Ulipristal Acetate [17]. In the case of recurrence, it is possible to propose a radical surgery which is likely to be decaying [7] [10]. Patients should therefore have a periodic gynecological follow-up associated with imaging, especially in the first year, when malignant degeneration of leiomyosarcoma [7] may occur.

The prognosis is usually good, except for the death reported in some cases of inextricable or metastatic tumors.

\section{Conclusion}

DPL is a disconcerting benign affection that simulates a peritoneal carcinomatosis, which must be recognized as such in order to avoid a dilapidated and unnecessary surgical procedure. Its discovery is fortuitous and often per-operative. It is characterized by a possible diffusion of the tumor to all the serous membranes, 
a break-in of these tissues and an unpredictable invasion of the contiguous organs. It is accompanied by a risk of leiomyosarcoma degeneration, requiring clinical and radiological (ultrasonography, CT scan or MRI) monitoring.

\section{References}

[1] Surmacki, P., Sporny, S., Tosiak, A. and Lasota, J. (2006) Disseminated Peritoneal Leiomyomatosis Coexisting with Leiomyoma of the Uterine Body. Archives of $G y^{-}$ necology and Obstetrics, 273, 301-303.

https://doi.org/10.1007/s00404-005-0086-y

[2] Altinok, G., Usobutun, A., Kucukali, T., Gunalp, S. and Ayhan, A. (2000) Disseminated Peritoneal Leomyomatosis. A Benign Entity Mimicking Carcino-matosis. Archives of Gynecology and Obstetrics, 264, 54-55. https://doi.org/10.1007/s004049900055

[3] Kouakou, F., Adjoby, R., Gondo, D., Loué, V., N’Guessan, K., Kouamé, A. and Effoh, D. (2012) Leiomyomatosis Peritonealis Disseminata: A Case Report. Clinical and Experimental Obstetrics and Gynecology, 39, 541-543.

[4] Al-Talib, A. and Tulandi, T. (2010) Physiopathologie et Possible Cause Iatrogène de Léiomyomatosis Péritonéalis Disséminée. Gynecologic and Obstetric Investigation, 69, 239-244. https://doi.org/10.1159/000274487

[5] Wu, C., Zhang, X., Tao, X., Ding, J. and Hua, K. (2016) Leiomyomatosis Peritonealis Disseminata: A Case Report and Review of the Literature. Molecular and Clinical Oncology, 4, 957-958. https://doi.org/10.3892/mco.2016.848

[6] Summa, B., Schem, C., Weigel, M., Strauss, A., Jonat, W., Maass, N., Schafer, F. and Bauerschlag, D.O. (2009) Leiomyomatosis Peritonealis Disseminata in Pregnant Woman. Archives of Gynecology and Obstetrics, 281, 123-127. https://doi.org/10.1007/s00404-009-1074-4

[7] Isly, H., Coiffic, J., Burtin, F., Ladure, H., Grall, J.Y. (2003) Léiomyomatose Péritonéale Diffuse: A Propos D'une Observation. Journal de Gynécologie Obstétrique et Biologie de la Reproduction, 32, 8.

[8] Thian, Y.L., Tan, K.H., Kwek, J.W., Wang, J., Chern, B. and Yam, K.L. (2009) Leiomyomatosis Disseminated Peritonealis and Subcutaneous Myoma: A Rare Complication of Laparoscopic Myomectomy. Abdominal Radiology, 34, 235-238. https://doi.org/10.1007/s00261-008-9379-5

[9] Miyake, T., Enomoto, T., Ueda, Y., Ikuma, K., Morii, E., Matsuzaki, S. and Murata, Y. (2009) A Case of Disseminated Peritoneal Leiomyomatosis Developing after Laparoscope-Assisted Myomectomy. Gynecologic and Obstetric Investigation, 67, 96-102. https://doi.org/10.1159/000164949

[10] Halama, N., Silke, A. and Grauling-Halama, I.D. (2005) Le Caractère Familial de Léiomyomatosis Peritonéalis Disséminée: Un Syndrome Génétique Inconnu? BMC Gastroenterology, 533-534.

[11] Yamaguchi, T., Imamura, Y., Yamamoto, T. and Fukuda, M. (2003) Léiomyomatosis Péritonéalis Disséminée Avec Transformation Maligne Chez un Homme. Pathologie International, 53,179-185. https://doi.org/10.1046/j.1440-1827.2003.01452.x

[12] Sharma, P., Chaturvedi, K.U., Gutpa, R. and Nigam, S. (2004) Léiomyomatosis Péritonéalis Disséminée Avec la Transformation Maligne D’Une Femme PostMénopausique. Gynecologic Oncology, 95, 742-745.

https://doi.org/10.1016/j.ygyno.2004.09.007 
[13] Hales, H.A., Peterson, C.M., Jones, K.P. and Quinn, J.D. (1992) Leiomyomatosis Peritonealis Disseminata Treated with a Gonadotropin-Releasing Hormone Agonist. A Case Report. American Journal of Obstetrics and Gynecology, 167, 515-516. https://doi.org/10.1016/S0002-9378(11)91445-8

[14] Carvalho, F.M., Carvalho, J.P., Pereira, R.M.A., Junior, C.B., Lacordia, R. and Baracat, E.C. (2012) Leiomyomatosis Peritonealis Disseminata Associated with Endometriosis and Multiple Uterus-Like Mass: Report of Two Cases. Clinical Medicine Insights: Case Reports, 5, 63-68. https://doi.org/10.4137/ccrep.s9530

[15] Parente, J.T., Levy, J., Chinea, F., Espinosa, B. and Brescia, M.J. (1995) Adjuvant Surgical and Hormonal Treatment of Leiomyomatosis Peritonealis Disseminata. A Case Report. The Journal of Reproductive Medicine, 40, 468-470.

[16] Lin, Y.C., Wei, L.H., Shun, C.T., et al. (2009) Disseminated Peritoneal Leiomyomatosis Responds to Systemic Chemotherapy. Oncology, 76, 55-58. https://doi.org/10.1159/000178761

[17] Verguts, J., Orye, G. and Marquette, S. (2014) Symptom Relief of Leiomyomatosis Peritonealis Disseminata with Ulipristal Acetate. Obstetrics \& Gynecology, 11, 57-58. https://doi.org/10.1007/s10397-013-0816-2

Submit or recommend next manuscript to SCIRP and we will provide best service for you:

Accepting pre-submission inquiries through Email, Facebook, LinkedIn, Twitter, etc. A wide selection of journals (inclusive of 9 subjects, more than 200 journals) Providing 24-hour high-quality service User-friendly online submission system Fair and swift peer-review system Efficient typesetting and proofreading procedure Display of the result of downloads and visits, as well as the number of cited articles Maximum dissemination of your research work

Submit your manuscript at: http://papersubmission.scirp.org/

Or contact ojog@scirp.org 